\title{
EFFECT OF POSTHARVEST THERMAL TREATMENTS ON REDUCING EXTERNAL CHILLING INJURY IN AVOCADO'FUERTE'CV. FRUITS
}

\author{
YASSIN, NAGLAA M. A. ${ }^{1}$, FATMA K. M. SHAABAN ${ }^{2}$ and \\ SAHAR M.A. ELETREBY ${ }^{2}$
}

1. Hort. Res. Station, Sabahia, Alex. Hort. Res. In., A.R.C. Giza Egypt

2. Hort. Res. Ins., Fruit Handling Dept. Hort. Res. In., A.R.C. Giza, Egypt

(Manuscript received 7 November 2016)

\begin{abstract}
$\mathrm{T}$ his experiment was carried out during 2013 and 2014 seasons on avocado (Persea americana Mill. cv. 'Fuerte') fruits to study the effect of postharvest treatments with hot air at $38^{\circ} \mathrm{C}$ for $(15,30,45 \mathrm{~min}$.) or dipping fruits in hot water at $46^{\circ} \mathrm{C}$ for $30 \mathrm{~min}$. All treated fruits were stored at $4 \pm 1^{\circ} \mathrm{C}$ and $90 \%$ relative humidity $(\mathrm{RH})$ to maintain fruit quality. Chilling injury percentage, weight loss, texture, soluble solids content (SSC), titratable acidity percentage, activity of polyphenol oxidase, peroxidase, oleic acid, linoleic acid and linolenic acid content were determined.

Fruit treated with hot air at $38^{\circ} \mathrm{C}$ for 15 or 30 min before cold storage was the best concerning to maintaining fruit quality and storability without significant difference between them.

Keywords: Avocado, heat treatment, chilling injury, polyphenoloxidase, peroxidase, oleic acid, linoleic acid, and linolenic acid
\end{abstract}

\section{INTRODUCTION}

Avocado (Persea americana Mill.) production areas around the world are typical remote from their overseas markets. Hence, there is often a significant delay between harvesting and the arrival of the fruit to the point of consumption, during this period fruit may ripen. Fruit for domestic markets may also be stored during times of over production. Thus, there is a need to develop an appropriate storage technology to delay ripening and provide quality produce for both local and export markets. Lidia et al, (2004) Although storage time and shelf life of avocado can be lengthened by lowering the storage temperature, chilling injury is induced below $7^{\circ} \mathrm{C}$ and this is a major factor influencing the quality of stored avocados. Heat treatment was a method used to reduce chilling injury. Heat treatments of Sharwil avocados at $37^{\circ} \mathrm{C}$ to $38^{\circ} \mathrm{C}$ hot air for 17 to $18 \mathrm{~h}$ reduced external chilling injury after storage at $1^{\circ} \mathrm{C}$ for 14 days for insect disinfestation purposes. However, the average external appearance of the heat treated fruit was only rated as 'marginally acceptable' which was blow a 'marketable 'rating. Florissen et al., (1996) reported a reduction in chilling injury of Hass fruits treated for 6 and $12 \mathrm{~h}$ at $38^{\circ} \mathrm{C}$ hot air. Fuerte avocado are susceptible to 
cold storage disorders. Reduction of susceptibility to these disorders using heat treatments would be advantageous to the export industry as improved quality fruit should fetch higher prices.

The aim of the present work was to study the effect of postharvest thermal treatments on fruit quality and reducing external chilling injury in avocado fruits.

\section{MATERIALS AND METHODS}

The present investigation was carried out during 2013 and 2014 seasons on 'Fuerte' avocado (Persea americana Mill.) grown in the experimental orchard of the Horticulture Research Station at El Kanater El Khayreia, Kalubia Governorate, Egypt. Mature fuerte fruits were harvested according to Kader (1985) who found that avocado reached maturity when dry weight of the flesh (17\% to $20.5 \%)$ depending on cultivar. Fruits were immediately transported to fruit handling department. Sound fruits were selected on the basis of uniformity of size and color. All Fruits were washed, air dried and divided into five groups as follows:

1. The first group was treated with Hot air at $38^{\circ} \mathrm{C}$ for $15 \mathrm{~min}$.

2. The second group was treated with Hot air at $38^{\circ} \mathrm{C}$ for $30 \mathrm{~min}$.

3. The third group was treated with Hot air at $38^{\circ} \mathrm{C}$ for $45 \mathrm{~min}$.

4. The forth group was treated with Hot water $46^{\circ} \mathrm{C}$ for $30 \mathrm{~min}$.

5. The fifth group was control (untreated fruits).

All treatments were packed in carton boxes in one layer. Every treatment consisted of three boxes (15 fruits/ box) and stored at $4 \pm 1^{\circ} \mathrm{C}$ and $90 \%$ relative humidity $(\mathrm{RH})$ for eight weeks. The changes in physical and chemical properties of fruits were evaluated every two weeks from the beginning to the end of storage period.

\section{Physical characteristics:}

\section{Fruit weight loss Percentage (FWL \%): -}

Six fruits were labeled in every replicate and were weighed before cold storage to get the initial weight, and then weighed after each period of cold storage. Fruits weight was recorded, then percentages of weight loss were calculated according to the following equation: -

$$
\mathrm{FWL} \%=[(\mathrm{Wi}-\mathrm{Ws}) / \mathrm{Wi}] \times 100
$$

Where, $\mathrm{Wi}=$ fruit weight at initial period.

$$
\text { Ws = fruit weight at sampling period. }
$$




\section{Texture:}

Pulp Texture was recorded by Ifra texture analyzer instrument, using a penetrating cylinder of $1 \mathrm{~mm}$ of diameter, to a constant distance $3 \mathrm{~mm}$ inside the pulp, and by a constant speed, $2 \mathrm{~mm} / \mathrm{sec}$, and the results were expressed as the resistance force to the penetrating tester, in units of pressure ( per gram )

\section{Chilling injury scale:}

Chilling injury (symptoms manifested in peel as discoloration or surface pitting or both) was rated on a scale of 1 to 5 where: $1=$ none, $2=$ trace, $3=$ slight, $4=$ moderate, $5=$ severe. According to Gregory et al. (1993).

\section{Chemical properties:}

\section{Soluble solids content (SSC):}

A hand refractometer was used to determine the percentage of soluble solids content in fruit juice.

\section{Titratable acidity (\%):}

Total acidity was determined by titrating $5 \mathrm{ml}$ of the extracted juice against $0.1 \mathrm{~N}$ of $\mathrm{NaOH}$ using phenolphethalin indicator, titratable acidity was expressed as percentage of citric acid ( $\mathrm{g}$ citric acid/100ml juice) according to (A.O.A.C, 2005).

\section{Polyphenoloxidase activity:}

The activity of polyphenoloxidase was measured as mentioned by Matta and Dimond (1963). The reaction mixture contains $1 \mathrm{ml}$ of the crude enzyme $+1 \mathrm{ml}$ phosphate buffer solution $(7.1 \mathrm{pH})+1 \mathrm{ml}$ catechol and completed with distilled water to $6.0 \mathrm{ml}$. Polyphnoloxidase was expressed as the change in the absorbance of the mixture every 0.5 minute for 5 minutes period at $495 \mathrm{~nm}$ by Spectrophotometer.

\section{Peroxidase activity:}

Peroxidase assay (based on oxidation of pyrogallol to purpyrogallin in the presence of $\mathrm{H}_{2} \mathrm{O}_{2}$ ) was determined according to the method described by Allan and Hollis (1972). The reaction mixture contains $0.3 \mathrm{ml}$ of the crude enzyme $+0.5 \mathrm{ml}$ phosphate buffer solution $\left(\mathrm{pH} \mathrm{7)}+0.3 \mathrm{ml}\right.$ pyrogallol $+1 \mathrm{ml} \mathrm{H}_{2} \mathrm{O}_{2}$. The mixture was completed with distilled water up to $3 \mathrm{ml}$. Peroxidase was expressed as the change in the absorbance of the mixture every 0.5 minute for 5 minutes period at $425 \mathrm{~nm}$ by Spectrophotometer.

\section{Fatty acids:}

Analysis and determination were carried out by preparation of methyl ester followed by the identification of methyl esters using an Agilent 6890 series gas 
chromatograph apparatus equipped with a DB23 $(60 \mathrm{~m} \times 0.32)$ (Stefanoudaki et al., 1999).

\section{Statistical Analysis:}

The experimental design was factorial Randomized complete block design (RCBD) with three replicates, and all the obtained data were statistically analyzed according to Snedecor and Cochran (1980). The individual comparisons were carried out by using the least significant difference (LSD at 5\%).

\section{RESULTS AND DISCUSSION}

\section{Physical properties:}

\section{Weight loss percentage (\%):}

Tabulated data in Table (1) it shows that, weight loss percentage was gradually significant increased with the elapse of the storage period in both seasons of study. The weight loss was attributed mainly to water loss from the fruit tissues and partially due to respiration process. Fruits treated by hot air for 45 min were lowest significantly in weight loss \% compared with all treatments in the both seasons on the average. These results were in line with those reported by Peter et al. (2002) on avocado 'Hass' cv fruits.

As for the interaction, significant differences between them. After 8 weeks of storage, fruits treated by hot air for $45 \mathrm{~min}$ were exhibited the lowest percentage (13.38 and $12.96 \%)$ of weight loss in the two seasons, respectively.

The mechanism of heat treatment causes changes in fruit ripening, such as inhibition of ethylene synthesis, and cell wall degrading enzymes, may be tied to changes in gene expression and protein synthesis. During a high temperature treatment the mRNA of fruit ripening genes disappear and those of heat shock proteins accumulate (Lurie et al., 1996).

\section{Texture $\left(\mathrm{g} / \mathrm{cm}^{2}\right)$ :}

Data obtained regarding fruit texture for seasons of 2013 and 2014 are presented in Table (2) it is clear that texture decreased with progress of storage periods in the two seasons, Yaman and Bayoindirli (2002) noticed that, the retention of firmness which occurred during storage could be explained by retarded degradation of insoluble protopectins to the more soluble pectic acid and pectin. During fruit ripening depolymerization or shortening of chain length of pectin substances occurs with an increase in pectinesterase and polygalactronase activities. 
There were significant differences among all treatments compared with control fruits in both seasons. Fruits were treated with hot water $\left(46^{\circ} \mathrm{C}\right.$ for $30 \mathrm{~min}$.) had significantly higher in texture fruits. The results agree with those of with Patrick et al, (2011) on mango, and Peter et al, (2002) on avocado.

As for interaction, at the end of storage fruits were treated with hot water $\left(46^{\circ} \mathrm{C}\right.$ for $30 \mathrm{~min}$.) exhibited higher values (118.6 and 121.6) of texture fruits in the two seasons, respectively. Heat treatment may inhibit protein synthesis required for cell wall degradation and ethylene synthesis (Lurie and Klein, 1990).

\section{Chilling injury:-}

Results presented in Table (3) revealed the effect of some postharvest thermal heat treatments on chilling injury $\%$ of avocado fruits stored at $4 \pm 1^{\circ} \mathrm{C}$ and 90\% RH, during 2013 and 2014 seasons. Chilling injury increased with prolonged storage period regardless of the used treatments. Up to 4 weeks of storage, no chilling injury symptoms were noticed on all treatments. Fruit treated with hot air for $15 \mathrm{~min}$ a $30 \mathrm{~min}$ exhibited the lowest values of chilling injury in the two seasons. Probably due to the induction of heat shock proteins (Florissen et al. 1996). While control treatment recorded the highest value of chilling injury in both seasons. These results are in line with those obtained by (Wang, 2010).

\section{Chemical properties:}

\section{Soluble solid content (SSC \%):}

The data introduced in Table (4) showed that, there were significant differences in soluble solid content of fruits. SSC \% gradually decreased with the advance in cold storage periods. Significant differences between the treatments were obtained during storage periods in most cases in the two seasons. Sugar content in the flesh tissues declined sharply as oil accumulation commenced. During postharvest storage at 1 or $5^{\circ} \mathrm{C}$, TSS in peel and flesh tissues declined slowly over the storage period. Substantial decreases in TSS, and especially in the C7 sugars, was observed in peel and flesh tissues during fruit ripening. These results suggest that the $\mathrm{C} 7$ sugars play an important role, not only in metabolic processes associated with fruit development, but also in respiratory processes associated with postharvest physiology and fruit ripening (Xuan Liu et al. 1999). Our results agree with Hassan et al., (2014) they found that SSC decrease in the fruits pulp as the storage period extends could be due to degradation of the complex in soluble compounds like sugars that are the major components of SSC content in the fruits.

SSC $\%$ of fruits treated with hot water $\left(46^{\circ} \mathrm{C}\right.$ for $\left.30 \mathrm{~min}\right)$ and hot air $\left(38^{\circ} \mathrm{C}\right.$ for $15 \mathrm{~min}$ ) had higher values in the two seasons, respectively. On the other hand, control 
fruits treatment exhibited the least percentage of SSC in both seasons. Our results are in line with those of Patrick et al, (2011).

Concerning the interaction between treatments and storage periods, after 8 weeks of storage fruits treated by hot water $\left(46^{\circ} \mathrm{C}\right.$ for $\left.30 \mathrm{~min}\right)$ recorded the highest percentage of SSC. On the other hand control treatment exhibited the lowest value in the two seasons.

\section{Titratable acidity:}

Data in Table (5) showed that significant decreases in titratable acidity of avocado fruits in both seasons with the progress of the storage period. Decrease in TA percentage could be due to the increase in its, consumption in the respiration activities as an organic substrate Wahba (2007).

Fruits treated with hot air for $45 \mathrm{~min}$ and fruits untreated were lower significantly in percentage of titratable acidity compared with other treatments in both season. These results agree with Peter (2002) on avocado.

As for interaction, no significant difference between treatments in the most cases.

\section{Polyphenol oxidase activity (PPO):-}

Data in Fig. (1) indicated that there was a gradual increase in polyphenol oxidase activity achieved at, the end of the storage periods. However, significant differences were noted between all treatments in the two seasons in most cases. The variation of enzymatic activity, in different maturation stages can be an indicator of the involvement of the enzyme in the last maturation stages of the fruit development in pineapple (Othman, 2012).

Fruit treated by hot air for 30 min had the lowest value of polyphenol oxidase activity in the two seasons. On the other hand control treatment recorded the highest value in both seasons, these results in line with Lucimara et al, (2010). It has been noted that heat stability of the enzyme may be related to ripeness of the fruits and in some cases it was also dependent on $\mathrm{PH}$. Different molecular form from the source may have different thermo stabilities (Deepaa and wong, 2012) in sweet potato.

\section{6-peroxidase activity:-}

Fig. (2) showed that the activity of peroxidase in avocado fruits, increased gradually throughout the storage periods. This result was in line with Othman (2012). No significant differences between all treatments in most cases. Hot water and hot air treatments for $30 \mathrm{~min}$ recorded the lowest values in activity of peroxidase in the two seasons, without any significant differences between them. While, control treatment had the highest values in the first and second seasons. These results agree with those of Lucimara et al, (2010). 


\section{Fatty acids:-}

Polyunsaturated fatty acids are very important for human nutrition as they are considered to be essential acids. Fig (3) indicated that the Linoleic (C18:2) and linolenic (C18:3) acids decreased throughout the storage periods with significant differences between all treatments in the most cases. These results agree with those of Plaza et al., (2003).

In the end of storage hot air treatment for $15 \mathrm{~min}$ had the least percentage of Linoleic acid while fruit treated by hot air for $45 \mathrm{~min}$ recorded the highest value.

As for Linolenic acid, fruit treated with hot air for $45 \mathrm{~min}$ gave the least value. On the other hand, hot air treatment for 30 min exhibited the highest percentage.

Oleic acid (C18:1) is the main monounsaturated fatty acid in avocado oils. Oleic acid increased gradually throughout the storage periods because these fatty acids preserve levels of high density lipoproteins and act as antioxidants (Richard et al., 2008). Significant differences were detected between all treatments in the most cases. Control treatment had the least value of Oleic acid. While, the highest value was recorded by hot air treatment for $15 \mathrm{~min}$. These result agree with Nahed et al. (2011) who noted that decrees in Linoleic and linolenic acids and increase the value of oleic acid in olive oil during stored fruits at $5^{\circ} \mathrm{C}$. The decrease in (C18:2) and (C18:3) were mainly due to the oxidation of unsaturated fatty acids into primary and secondary oxidation products, which decreased the percentage of unsaturated fatty acids composition. While, the increases in oleic acid was relatively occurred as a result of the decrease in Linoleic and linolenic acids.

\section{CONCLUSION}

Hot air at $38^{\circ} \mathrm{C}$ for 15 or 30 min treatments were the best concerning to maintain fruit quality, storability and reducing chilling injury compared with other treatments . 


\section{Tables}

Table 1. Effect of postharvest thermal treatments on weight loss \% of avocado 'Fuerte' fruits stored at $4 \pm 1{ }^{\circ} \mathrm{C}$ and $90 \%$ RH during 2013 and 2014 seasons.

\begin{tabular}{|c|c|c|c|c|c|}
\hline \multirow{2}{*}{ Treatments } & \multicolumn{4}{|c|}{ Storage periods weeks 2013} & \multirow{2}{*}{ Means(A) } \\
\hline & 2 & 4 & 6 & 8 & \\
\hline Hot air $15 \min$ & 3.02 & 7.98 & 13.41 & 17.64 & $8.41 \mathrm{~A}$ \\
\hline Hot air 30min & 1.61 & 5.43 & 9.62 & 13.47 & $6.03 B$ \\
\hline Hot air 45min & 1.52 & 4.86 & 9.72 & 13.38 & $5.90 \mathrm{~B}$ \\
\hline Hot water $46^{\circ} \mathrm{C}$ & 2.89 & 7.34 & 12.77 & 18.17 & $8.23 \mathrm{~A}$ \\
\hline Control & 2.02 & 7.05 & 11.12 & 15.70 & $7.18 A B$ \\
\hline Means(B) & $2.21 d$ & $6.53 c$ & $11.33 b$ & $15.67 a$ & \\
\hline \multirow{2}{*}{ L.S.D at $5 \%$ level } & $A$ & $B$ & $A^{*} B$ & & \\
\hline & 1.558 & 1.558 & 3.484 & & \\
\hline \multicolumn{6}{|c|}{ Storage periods weeks 2014} \\
\hline Treatments & 2 & 4 & 6 & 8 & Means(A) \\
\hline Hot air $15 \mathrm{~min}$ & 1.93 & 7.64 & 12.63 & 16.41 & $7.72 \mathrm{~A}$ \\
\hline Hot air 30min & 1.91 & 7.56 & 13.27 & 16.37 & $7.82 \mathrm{~A}$ \\
\hline Hot air45min & 1.68 & 4.44 & 9.59 & 12.96 & $5.73 C$ \\
\hline Hot water $46^{\circ} \mathrm{C}$ & 2.46 & 5.97 & 10.98 & 15.48 & $6.98 \mathrm{AB}$ \\
\hline Control & 2.18 & 6.06 & 9.95 & 13.36 & $6.31 \mathrm{~B}$ \\
\hline Means(B) & $2.03 d$ & $6.33 c$ & $11.28 \mathrm{~b}$ & $14.92 a$ & \\
\hline \multirow{2}{*}{ L.S.D at $5 \%$ level } & $A$ & $B$ & $A * B$ & & \\
\hline & 1.038 & 1.038 & 0.8037 & & \\
\hline
\end{tabular}

Table 2. Effect of postharvest thermal treatments on Texture at $3 \mathrm{~mm}$ depth $(\mathrm{g} / \mathrm{cm} 2)$ of avocado 'Fuerte' fruits stored at $4 \pm 1^{\circ} \mathrm{C}$ and $90 \% \mathrm{RH}$ during 2013 and 2014 seasons.

\begin{tabular}{|c|c|c|c|c|c|c|}
\hline \multirow{2}{*}{ Treatments } & \multicolumn{5}{|c|}{ Storage periods weeks 2013} & \multirow{2}{*}{ Means(A) } \\
\hline & 0 & 2 & 4 & 6 & 8 & \\
\hline Hot air15min & 163.6 & 152.3 & 148.0 & 132.0 & 102.0 & 139.58B \\
\hline Hot air30min & 163.6 & 142.3 & 137.0 & 125 & 108.3 & $135.24 C$ \\
\hline Hot air 45min & 163.6 & 142.0 & 129.0 & 112.3 & 95.3 & $128.44 \mathrm{D}$ \\
\hline Hot water $46^{\circ} \mathrm{C}$ & 163.6 & 157.0 & 141.3 & 131.6 & 118.6 & $142.42 \mathrm{~A}$ \\
\hline Control & 163.6 & 131.3 & 120.6 & 77.3 & 51.6 & $108.88 \mathrm{E}$ \\
\hline Means(B) & $163.6 a$ & $144.98 b$ & $135.18 \mathrm{c}$ & $115.64 d$ & $95.16 \mathrm{e}$ & \\
\hline \multirow{2}{*}{ L.S.D at 5\% level } & A & $B$ & $A * B$ & & & \\
\hline & 2.331 & 2.331 & 5.212 & & & \\
\hline \multicolumn{7}{|c|}{ Storage periods weeks 2014} \\
\hline Treatments & 0 & 2 & 4 & 6 & 8 & Means(A) \\
\hline Hot air $15 \mathrm{~min}$ & 154.3 & 148.3 & 129.6 & 106.6 & 90.3 & $125.82 \mathrm{C}$ \\
\hline Hot air 30min & 154.3 & 142.6 & 115.3 & 105.0 & 100.6 & $123.56 \mathrm{CD}$ \\
\hline Hot air 45min & 154.3 & 135.3 & 132.3 & 128.3 & 105.6 & 131.16B \\
\hline Hot water $46^{\circ} \mathrm{C}$ & 154.3 & 148.3 & 139.6 & 131.3 & 121.6 & $139.02 \mathrm{~A}$ \\
\hline Control & 154.3 & 143.0 & 138.3 & 109.6 & 63.0 & 121.64D \\
\hline Means(B) & $154.3 a$ & $143.50 \mathrm{~b}$ & $131.02 \mathrm{c}$ & $116.16 \mathrm{~d}$ & $96.22 \mathrm{e}$ & \\
\hline \multirow{2}{*}{ L.S.D at $5 \%$ level } & A & $B$ & $A * B$ & & & \\
\hline & 2.437 & 2.437 & 5.450 & & & \\
\hline
\end{tabular}


Table 3. Effect of some post-harvest thermal treatments on chilling injury scale of avocado 'Fuerte' fruits stored at $4 \pm 1^{\circ} \mathrm{C}$ and $90 \% \mathrm{RH}$, during 2013 and 2014 seasons.

\begin{tabular}{|c|c|c|c|c|c|}
\hline \multirow{2}{*}{ Treatments } & \multicolumn{4}{|c|}{ Storage periods weeks 2013} & \multirow{2}{*}{ Means } \\
\hline & 2 & 4 & 6 & 8 & \\
\hline Hot air $15 \mathrm{~min}$ & 1 & 1 & 1 & 2 & 1.2 \\
\hline Hot air 30min & 1 & 1 & 1 & 2 & 1.2 \\
\hline Hot air 45min & 1 & 1 & 2 & 3 & 1.8 \\
\hline Hot water $46^{\circ} \mathrm{C}$ & 1 & 1 & 2 & 4 & 2.0 \\
\hline Control & 1 & 1 & 3 & 5 & 2.5 \\
\hline Means & 1 & 1 & 1.8 & 3.2 & \\
\hline \multicolumn{6}{|c|}{ Storage periods weeks 2014} \\
\hline Treatments & 2 & 4 & 6 & 8 & Means \\
\hline Hot air $15 \mathrm{~min}$ & 1 & 1 & 1 & 1 & 1.0 \\
\hline Hot air 30min & 1 & 1 & 1 & 2 & 1.2 \\
\hline Hot air45min & 1 & 1 & 2 & 3 & 1.8 \\
\hline Hot water $46^{\circ} \mathrm{C}$ & 1 & 1 & 2 & 4 & 2.0 \\
\hline Control & 1 & 1 & 3 & 4 & 2.3 \\
\hline Means & 1 & 1 & 1.8 & 2.8 & \\
\hline
\end{tabular}

Table 4. Effect of postharvest thermal treatments on soluble solids content \% of avocado 'Fuerte' fruits stored at $4 \pm 1^{\circ} \mathrm{C}$ and 90\%RH during 2013 and 2014 seasons.

\begin{tabular}{|c|c|c|c|c|c|c|}
\hline \multirow{2}{*}{ Treatments } & \multicolumn{5}{|c|}{ Storage periods weeks 2013} & \multirow{2}{*}{ Means(A) } \\
\hline & 0 & 2 & 4 & 6 & 8 & \\
\hline Hot air $15 \mathrm{~min}$ & 19 & 17 & 15 & 14 & 13 & $15.6 \mathrm{~B}$ \\
\hline Hot air30min & 19 & 16 & 14 & 13.5 & 13 & $15.1 \mathrm{D}$ \\
\hline Hot air45min & 19 & 15.5 & 15 & 14 & 13 & $15.3 \mathrm{C}$ \\
\hline Hot water $46^{\circ} \mathrm{C}$ & 19 & 16 & 15.5 & 15 & 15 & $16.1 \mathrm{~A}$ \\
\hline Control & 19 & 16 & 15 & 11.9 & 11.5 & 14.7E \\
\hline Means (B) & $19.0 \mathrm{a}$ & $16.1 b$ & $14.9 \mathrm{c}$ & $13.7 d$ & $13.1 \mathrm{e}$ & \\
\hline \multirow{2}{*}{ L.S.D at 5\% level } & $\mathrm{A}$ & $\mathrm{B}$ & $A * B$ & & & \\
\hline & 0.05191 & 0.05191 & 0.1161 & & & \\
\hline \multicolumn{7}{|c|}{ Storage periods weeks 2014} \\
\hline Treatments & 0 & 2 & 4 & 6 & 8 & Means(A) \\
\hline Hot air15min & 18 & 16.5 & 15.5 & 15 & 13.5 & $15.7 \mathrm{~A}$ \\
\hline Hot air 30min & 18 & 16 & 14.5 & 14 & 13 & $15.1 \mathrm{C}$ \\
\hline Hot air45min & 18 & 16 & 15 & 14 & 13.5 & $15.2 \mathrm{~B}$ \\
\hline Hot water $46^{\circ} \mathrm{C}$ & 18 & 15 & 14.5 & 14 & 14.5 & $15.0 \mathrm{D}$ \\
\hline Control & 18 & 15 & 14 & 12.5 & 12 & $14.3 \mathrm{E}$ \\
\hline Means(B) & $18.0 \mathrm{a}$ & $15.7 \mathrm{~b}$ & $14.7 \mathrm{c}$ & $13.9 d$ & $13.0 \mathrm{e}$ & \\
\hline \multirow{2}{*}{ L.S.D at $5 \%$ level } & $\mathrm{A}$ & $\mathrm{B}$ & $A * B$ & & & \\
\hline & 0.04021 & 0.04021 & 0.08992 & & & \\
\hline
\end{tabular}


EFFECT OF POSTHARVEST THERMAL TREATMENTS ON REDUCING EXTERNAL CHILLING INJURY IN AVOCADO'FUERTE'CV. FRUITS

Table 5. Effect of postharvest thermal treatments on titratable acidity \% of avocado 'Fuerte' fruits stored at $4 \pm 1^{\circ} \mathrm{Cand} 90 \% \mathrm{RH}$ during 2013 and 2014 seasons.

\begin{tabular}{|c|c|c|c|c|c|c|}
\hline \multicolumn{7}{|c|}{ Storage periods weeks 2013} \\
\hline Treatments & 0 & 2 & 4 & 6 & 8 & Means(A) \\
\hline Hot air $15 \min$ & 0.32 & 0.18 & 0.16 & 0.13 & 0.07 & $0.17 \mathrm{~A}$ \\
\hline Hot air 30min & 0.32 & 0.19 & 0.15 & 0.09 & 0.07 & $0.17 \mathrm{~A}$ \\
\hline Hot air 45min & 0.32 & 0.16 & 0.12 & 0.09 & 0.06 & $0.15 \mathrm{~B}$ \\
\hline Hot water $46^{\circ} \mathrm{C}$ & 0.32 & 0.19 & 0.160 & 0.10 & 0.09 & $0.17 \mathrm{~A}$ \\
\hline Control & 0.32 & 0.13 & 0.06 & 0.04 & 0.02 & $0.12 \mathrm{~B}$ \\
\hline Means(B) & $0.32 \mathrm{ab}$ & $0.17 \mathrm{~b}$ & $0.13 c$ & $0.09 c$ & $0.06 \mathrm{bc}$ & \\
\hline S D & A & B & $A * B$ & & & \\
\hline L.S.D at $5 \%$ level & 0.06567 & 0.06567 & 0.1468 & & & \\
\hline \multicolumn{7}{|c|}{ Storage periods weeks 2014} \\
\hline Treatments & 0 & 2 & 4 & 6 & 8 & Means(A) \\
\hline Hot air 15min & 0.35 & 0.19 & 0.13 & 0.12 & 0.07 & $0.17 \mathrm{AB}$ \\
\hline Hot air 30min & 0.35 & 0.22 & 0.16 & 0.13 & 0.06 & $0.18 \mathrm{AB}$ \\
\hline Hot air45min & 0.35 & 0.16 & 0.10 & 0.08 & 0.06 & $0.15 \mathrm{AB}$ \\
\hline Hot water $46^{\circ} \mathrm{C}$ & 0.35 & 0.26 & 0.23 & 0.18 & 0.09 & $0.22 \mathrm{~A}$ \\
\hline Control & 0.35 & 0.15 & 0.06 & 0.05 & 0.03 & $0.13 \mathrm{~B}$ \\
\hline Means(B) & $0.35 a$ & $0.19 b$ & $0.14 b c$ & $0.11 \mathrm{c}$ & $0.06 \mathrm{c}$ & \\
\hline \multirow{2}{*}{ L.S.D at $5 \%$ level } & A & B & $\mathrm{A} * \mathrm{~B}$ & & & \\
\hline & 0.07873 & 0.07873 & 0.1761 & & & \\
\hline
\end{tabular}



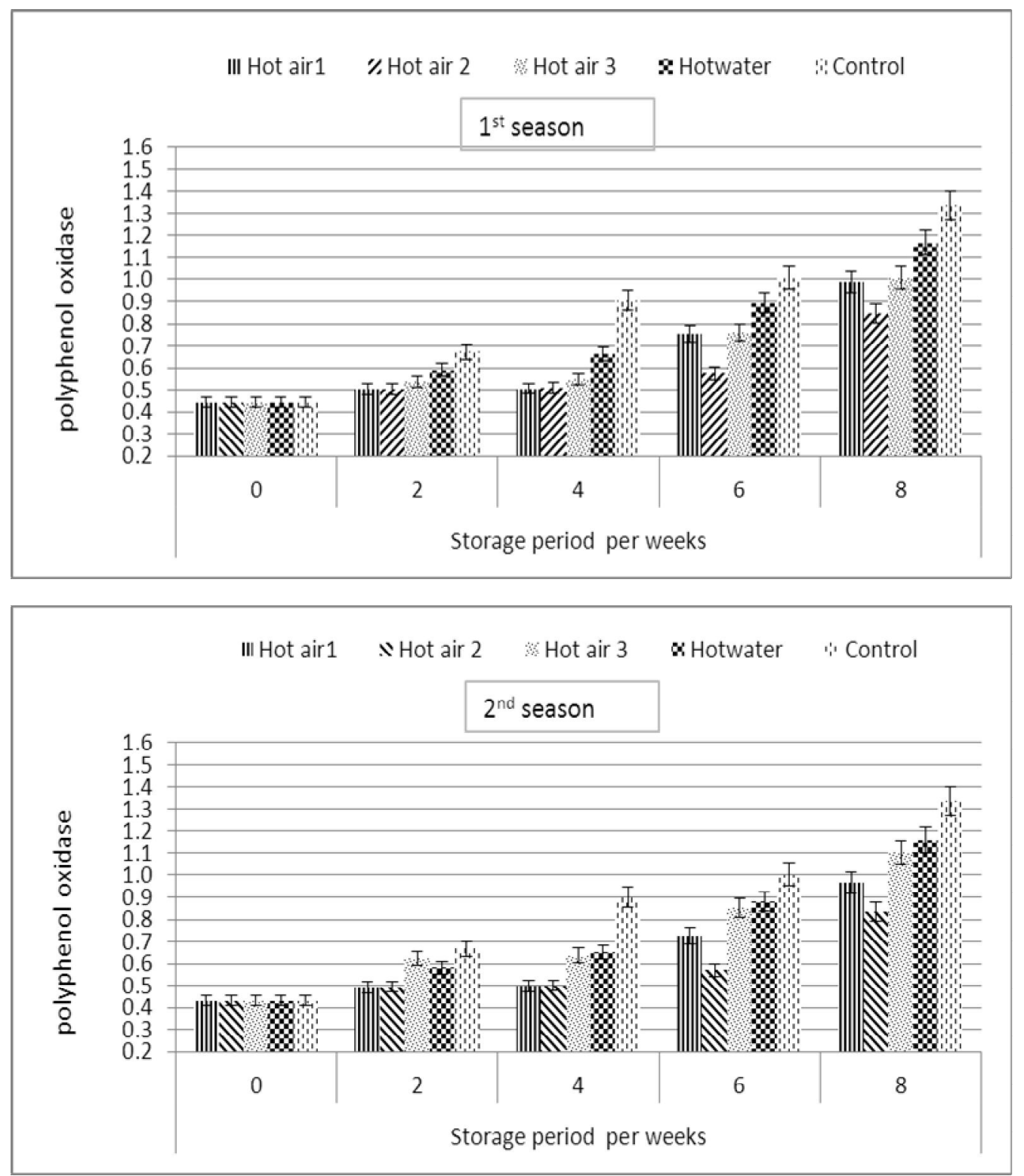

Fig 1. Effect of some post-harvest thermal treatments on polyphenol oxidase activity of avocado fruits stored at $4 \pm 1^{\circ} \mathrm{C}$ and $90 \% \mathrm{RH}$, during 2013. and 2014 seasons. 

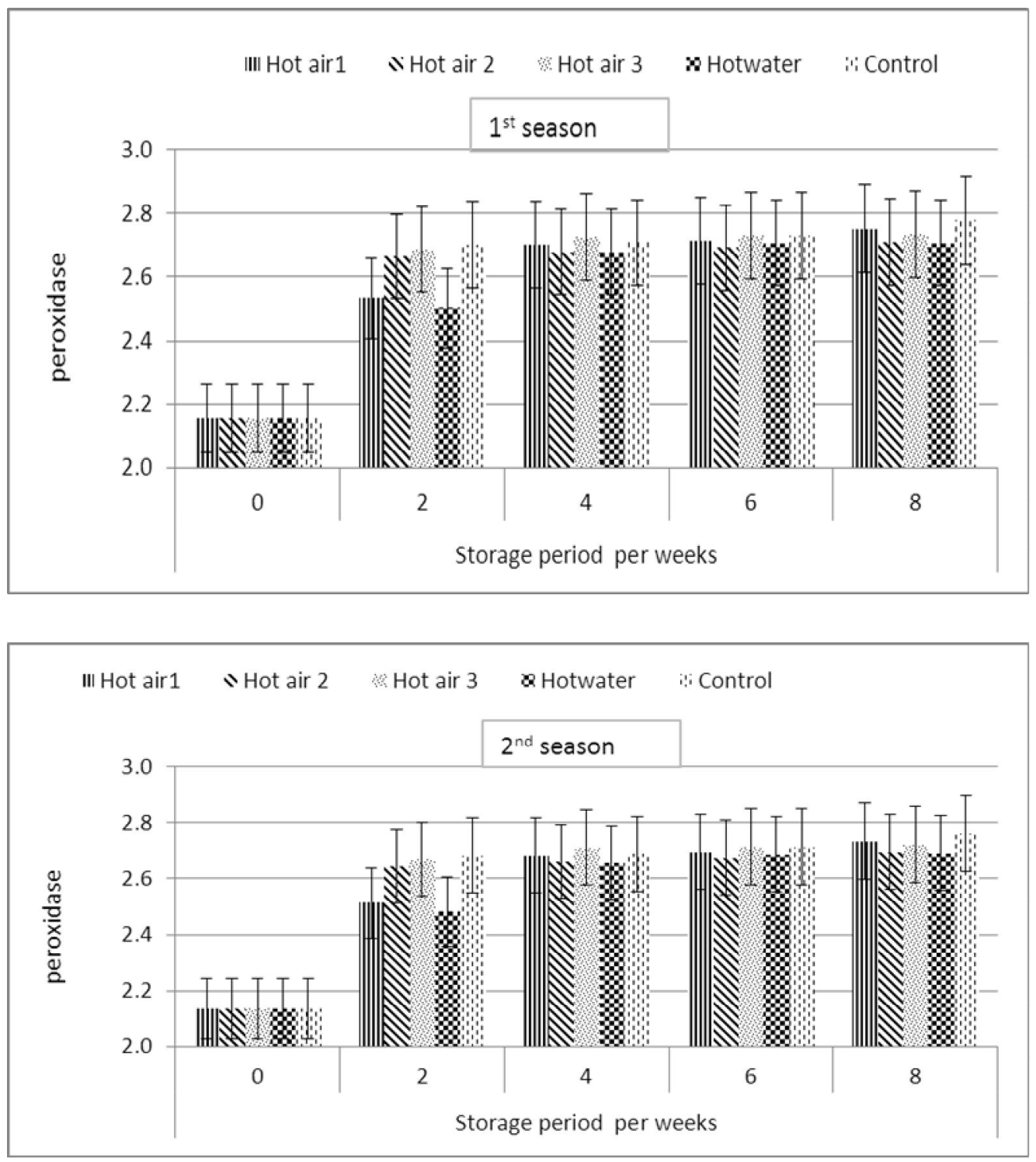

Fig 2. Effect of some post-harvest thermal treatments on peroxidase activity of avocado fruits stored at $4 \pm 1^{\circ} \mathrm{C}$ and $90 \% \mathrm{RH}$, during 2013 and 2014 seasons. 

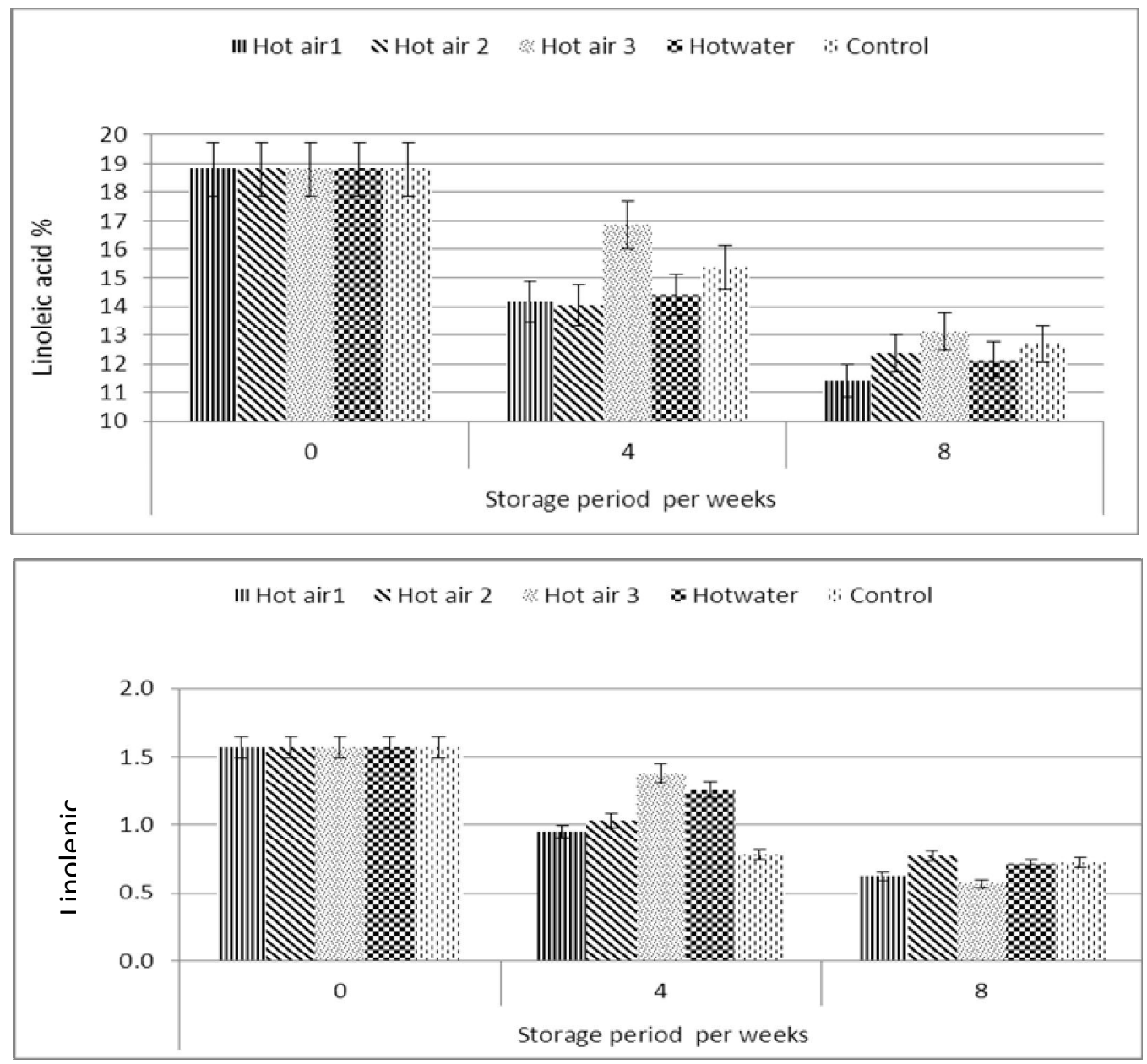

III Hot air 1 s Hot air 2 Hot air $3 \quad \&$ Hotwater it: Control

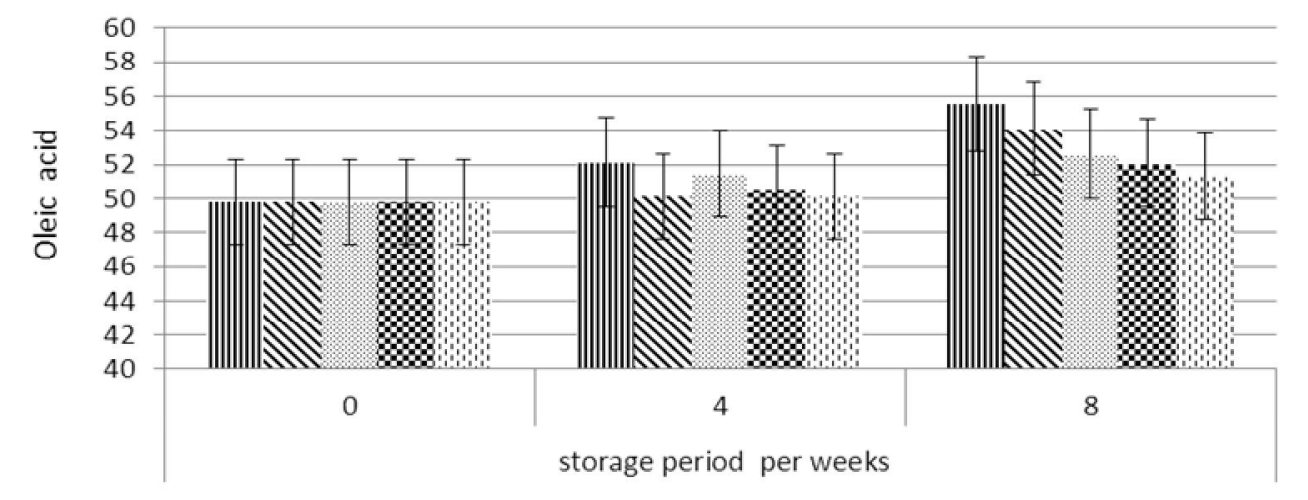

Fig. 3. Effect of some post-harvest thermal treatments on Fatty acids of avocado fruits stored at $4 \pm 1{ }^{\circ} \mathrm{C}$ and $90 \% \mathrm{RH}$, during 2014 season. 


\section{REFERENCES}

1. Allan, A. I. and J. P. Hollis. 1972. Sulfide inhibition of Oxidases In rice roots. Phytopathology 62: 634-636.

2. A.O.A.C. 2005. Official Methods of Analysis. $18^{\text {th }}$ ed. Association of Official Analysis Chemists. Washington, D.C., USA.

3. Deepaa M. and Wong C.W. 2012. Characterization of polyphenol oxidase in sweet potato (Ipomoea batatas(L.)). Journal for the advancement of science \& arts.vol3,no1

4. Florissen, P., J. S. Ekman, C. Blumenthel W. B. MC. Glasson, J. Conroy and P. Holforrd. 1996. The effects of short heat treatments on the induction of chilling injury in avocado fruits (Persea American Mill). Postharvest biology and technology 8(129-141).

5. Gregory, Gr.; D. McCollum; A. Salvatore and R. E. McDonald. 1993. Heat treatment inhibits mango chilling injury. HortScience, 28 (3): 197- 198.

6. Hassan Z. H., Lesmayati, S., Qomariah, R. and Hasnianto, A. 2014. Effect o wax coating application and storage temperatures on the quality of tangerine citrus (citrus reticulate) var. Siam Banjar. International food research journal 21(2): 641-648.

7. Klein, J. D. and S. Lurie. 1990. Pre storage heat treatment as a means of improving poststorage quality of apples. J. Amer. Soc. Hort. Sci. 115:265269.

8. Lidia D.,Lidia P., and Alicia O. 2004. Avocado postharvest operation. Food and agriculture organization of the United Nations 15(6).

9. Lucimara S., Vanini, Angela, K. and E. Clemente. 2010. Polyphenoloxidase and peroxidase in avocado pulp (Persea Americana Mill).Cienc.Tecnol. Aliment., caminas 30(2)525-531.

10. Lurie, S., Handros, A., Fallik, E., Shapira, R., 1996b. Reversible inhibition of tomato fruit gene expression at high temperature. Plant Physiol. 110, 12071214.

11. Matta, A. I. and A. F. Dimond. 1963. Symptoms of Fusarium wilt in relation to quantity of fungus and enzyme activity in tomato stems. Phytopathol., 53: 574-578.

12. Nahed M. M. Atta, A. A. Azza and I. I. Awatif. 2011. Changes in the orgnoleptic characteristics and quality of olive oil during fruits storage at low temperature. Minufiya J. Agric. Res. 36 (4) 829-843. 
13. Othman O. C. 2012. Polyphenoloxidase and perioxidase activity during open air ripening storage of pineapple (Ananas Comosus L.), Mango (Mangifera Indica) and papaya (carica Papaya) fruits grown in Dar Es Salaam, Tanzania. Tanz. j. sci. 38 (3).

14. Patrick K., F. Appiah and J. K. O, Debrah. 2011. Effect of hot water treatment on quality and shelf life of keitt mango. Agriculture and biology journal of North America p: 2151-7517

15. Peter J. H. , B. A. Stubbings, M. F. Adkins, G. F. Meiburg and A. B. Woolf. 2002. Hot water improve Hass avocado fruit quality after cold disinfestation. Postharvest biology and technology (Impact factor :2.22).no 24 vol 2 p:183192.

16. Plaza D. L., P. Ruperez, M. Montoya. 2003. Fatty acids distribution in 'Hass' avocado during storage with ethylene absorber at subcritical temperature. Acta. hort.600(68).

17. Richard, D., Kefi, K., Barbe,U.Bausero., P. and Visioli, F. 2008. Polyunsaturated fatty acids as antioxidants. Pharmacological research 57 (6) 451-455

18. Snedecor, G. W. and W. G. Cochran. 1980. Statistical Methods. 7th ed., 4th printing, the Iowa state Univ. Press Ames., Iowa U.S.A.

19. Stefanoudaki, E.; Kotsifaki, F. and Koutsaftakis, A. 1999. Classification of virgin olive olive oils of the two major Cretan cultivars based on their fatty acid composition. J.Am. Oil Chem. Soc. 76: 623-626.

20. Wahba, M. M. 2007. Physiological studies on the response of 'Costata' persimmon trees to biofertilization. Ph. Thesis Fac. Of Agric. Al-Azhar Uni.

21. Wang.C. Y. 2010. Allivation of chilling injury in tropical and subtropical fruits. Acta.hort.864.

22. Xuan Liu, Paul W. Robinson, Monica A. Madore, Guy W. Witney,1 and Mary Lu Arpaia. 1999. 'Hass' Avocado Carbohydrate Fluctuations. II.Fruit Growth and Ripening. J. Amer. Soc. Hort. Sci. 124(6):676-681. 1999.

23. Yaman O, Bayoindirli L. 2002. Effects of an edible coating and cold storage on shelf- life and quality of cherries. Lebensm- Wiss. Und- Technol 35:146-150. 


\section{تأثير المعاملات الحرارية بعد الحصاد لتقليل اضرار البرودة الخارجية على ثمار الافوكادو صنف فيورت}

نجلاء محمد عبد الرحيم ياسين فاطمة قرنى محمد شعبان سحر محمد على الاتربى ا ـ محطة بحوث البساتين بالصبحية اسكندرية- معه بحوث البساتين - مركز البحوث الزراعية

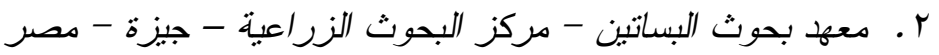

أجريت هذه الدراسة خلال موسمى rا .ب و ـ ا.بr على ثمار الافوكادو صنف الفيورت

لمعرفة تاثير المعاملات الحرارية على تقليل أضرار البرودة والمحافظة على جودة الثمار و ذلك بتعريض الثمار للهو اء الساخن 38 درجة مئوية لمدة (0 او • بو 0؛ دقيقة) أو بغمر الثمار فى الماء الساخن 46 درجة مئوية لمدة ·ب دقيقة وخزنت ثمار المعاملات على ع درجة مئوية ، .9\% رطوبة نسبية ونم تقدير أضر ار البرودة و الفقد فى الوزن و الصلابة ومحتوى الثمار من المو اد الصلبة الذائبة ونسبة الحموضة ونشاط كلا من أنزيمى البوليفينول أوكسيديز و البيروكسيديز ومحتوى الثمار من حمض الاوليك وحض اللينولينيك و اللينوليك .

وقد أوضحت النتائج ان معاملة الثمار بالهواء الساخن مب درجة مئوية لددة 10 أو .ب دقيقة قبل التخزين المبرد كانت فعالة فى المحافظة على الجودة والقدرة التخزينية لثمار الافوكادو . 